\title{
Back to the Roots, the Origins and the Beginning: Re- flections on Revival (tajdid) in Islamic Discourse
}

\author{
ABDULKADER TAYOB \\ University of Cape Town
}

\begin{abstract}
Revival takes on many different forms in Muslim societies. This article explores and identifies a hadith discourse of revival, based on a famous hadith and its commentary that promises renewal at the head of every century. Using an inter-textual analysis, it argues that revival was rooted in the first crisis faced by the early Muslim community when the Prophet died and could no longer personally guide Muslims. Across time and place, the discourse of revival confronts this original crisis by naming and renaming it, and offering a resolution. I also suggest that the first crisis was beyond resolution, as according to Muslim belief the prophetic line of succession ended with Muhammad. The discourse of revival thus became potentially recurrent, as resolution was always prone to disruption.
\end{abstract}

Keyvwords: Islam, revival, discourse, hadīth, intertextuality,

The idea of returning to the beginning is clearly identifiable in the Islamic tradition. Muslims quote the Qur'an and statements attributed to the Prophet to justify and guide ritual, behaviour and beliefs. Much of the scholarly legacy of Islam is built on this gaze to the origins. The return to a point of origin, a new beginning, promises unity of purpose and vision, but has in practice led to greater complexity, disunity and conflict. Islamic revival in modern times is usually traced to the 1970s, and interpreted as a response to the failure of secular ideologies and nations to deliver prosperity in postcolonial states. In the 18th century, religious movements in West Africa, the Arabian Peninsula and the Indian subcontinent challenged existing traditions on state, society, rituals and beliefs (Dallal 1993). They justified their puritan discourse in terms of a return to the beginning. For the 19th century, B. G. Martin traced new or revitalized Sufi orders across Africa that urged Muslims to return to the Prophet and the early generation of Muslims for inspiration to create new societies, new modes of mystical visions, and also resistance against colonial armies (Martin 1976). Towards the end of the 
19th century, another form of 'turning to the past' emerged among Muslim intellectuals in India, Russia, Egypt, Syria, Iran and the Ottoman Empire. This time the turn to the origins attempted to create an indigenous Islamic modernism (Ahmad 1967). At the same time, more traditional scholars in India and elsewhere invoked revival to create a cultural bulwark against European modernism and colonialism (Metcalf 2002). In the growing metropolitan colonial cities, school teachers and journalists like Hasan al-Banna and Maududi proposed a return to the origins in the mirror of nationalist and socialist ideologies. Their ideas became popular in the 1970s, and then took on new forms, alternately radical and democratic, in different national and global contexts (Humphreys 1982). Through the global impact of Saudi Arabia, Salafism has become another form of revival (Meijer 2009). The return to origins in revival movements has taken on many different forms in the last two to three hundred years. Focussing only on the major trends and tendencies, the turn to the origins of Islam created anti-Sufi movements, new Sufi Movements, modernisms, religious ideologies and individualized religious paths. The search for revival, it seems, has no end-point and will probably generate more variety and complexity in the future.

Revival merits closer attention as part of a shared Muslim discourse that constitutes Muslim traditions. Gellner used the metaphor of a pack of cards to refer to some common distinguishing features in the sociology of Islam. Such cards, Gellner argued, were 'trans-ethnic and trans-social', and took on different configurations in different contexts (Gellner 1981, 100). Gilsenan expressed the same sentiment by referring to 'the basic building blocks [that] [...] are largely shared [...]' by Muslims (Gilsenan 1990, 15). Working with contemporary Islamist movements, Roff proposed a discourse that was easily recognizable both in Cairo and Jakarta (Roff 1987). Talal Asad has urged scholars of Islam and Christianity to recognize discursive traditions that contribute to 'the formation of moral selves, the manipulation of populations (or resistance to it), and the production of appropriate knowledges' (Asad 1986, 7). In this article, I explore revival and its meaning and significance within a shared Muslim religious discourse.

Turning attention to the etic terms used for revival, I identify a recurring pattern in the discourse of revival. The words mujaddid (reviver) and tajdid (revival) appear regularly in Muslim discourse. Their original reference is taken from a hadith narration wherein the Prophet Muhammad predicted the emergence of a renewer (mujaddid) at the turn of every century. Such individuals became the subject of a long tradition of both scholarly and popular usage. I argue in this article that the hadith literature and com- 
mentary suggest not only unity and resolution, but also irresolvable crisis. Revival has always to be renegotiated when the origin is sought. I explore the roots of promise, instability and chaos in the hadith discourse of revival, and suggest that the plurality and contestation of revivalist groups in the modern world were reflected and prefigured in this discourse.

\section{Origins in the Study of Religions}

The hadith discourse of revival may be located between an Eliadean approach to origins, and deconstructionist and contextualist approaches that shun any essential meaning in religious discourse. Phenomenologists like Mircea Eliade posited the origins as an ideal and liminal time and place, re-enacted in myth and ritual. Critical scholars have rightly questioned the assumptions and theologies written into such interpretations, but they have not offered an interpretation of how to understand religious discourses that turn to the origins. What are the roots of such gazes to the past? And what do they mean? This article takes a step in this direction with respect to the turn to origins in Muslim discourse.

Eliade is well known for his theory on the deep phenomenology of turning to the origins in myth and ritual. In his theory of the 'eternal return', he believed that religions provided access to remember and re-enact the first encounters with the absolute and the universal (Eliade 1959). Myth and ritual were encounters with the sacred, obliterating the negative effects of materiality and history. They were exemplary structures for human beings searching for the absolute. In a reflective piece on the subject of origins, Eliade also applied this theory to the modern scholarly search for origins. Beginning with the Renaissance, he pointed out how European intellectuals had been searching for such foundations and origins. This search had led them to devote greater attention to history and to materiality. The modern scholar of religion should follow a different path. She ought to recognize the search for origins as a window to the sacred itself: 'We know that we can grasp the sacred only through manifestations which are always historically conditioned' (Eliade 1964,168). Eliade urged the historian of religion to work with the particular, but to not forget the universal: 'He knows that he is condemned to work exclusively with historical documents, but at the same time he feels that these documents tell him something more than the simple fact that they reflect historical situations' (Eliade 1964, 169). Rituals and myths of religious traditions reveal universal categories that the scholar of religions ought to recognize and identify. Eliade argues that the study of 
myths and rituals in the history of religions may help human societies to grasp the essential and universal meaning of life again.

Tomako Masuzawa has cast a critical eye on this scholarly search for origins, and rejected the deeply felt yearning for the origins as universals as reflected in Eliade's work (Masuzawa 1989; 2000). She agrees with Eliade that the search for origins has preoccupied European intellectuals, but proposes a critical genealogical approach to such obsessions. Turning to the origins was not a deep yearning for an elusive universal, but a desire to promote 'other things'. The scholar must uncover these 'other things' that masquerade as universals (Masuzawa 2000; Foucault 1977). Masuzawa argues that there is no deep meaning in the return to the past and to the origins. One should rather ask why philosophers, anthropologists and historians of religion have been fascinated and obsessed with origins. In an article on artists, Masuzawa identifies their search for origins as hopeless attempts to recover the original in a world dominated by photographic reproductions (Masuzawa 1989). Such artists are confronted by the 'threat' posed by the camera. Masuzawa's critical reflections turned attention to origins as a masque for other interests, threats and pre-occupations; her critical reflections ask scholars to turn their attention to the production of studies focussed on origins.

These critical reflections are valuable, but they do not shed light on the phenomenon of 'turning to the origins' in religious discourse. Many religions in general, and Islam in particular, engage in this search for and gaze to the origins. Bryan Turner offers a better option in his study of the turn to the origins within religious traditions (Islam and Christianity, in his analysis). He recalls a theme from Max Weber on the origins of a tradition when there was a clear socio-economic ethic that dominated a particular tradition. According to Weber, this central ethic 'receives its stamp primarily from religious sources, and first of all, from the content of its annunciation and its promise' (Gerth \& Mills 1970, 269). Accordingly, such 'annunciations' and 'promise(s)' leave a lasting impact on a religious tradition. This idea is closely connected with charisma and routinization. The charismatic leader initiates change, which is followed by routinization that carries the weight and mark of such change into its future (Gerth \& Mills 1970, 269). Turner developed this idea to understand the link between a tradition's turn to origins and its subsequent history; he sees this pattern of turning to the origins as playing a conservative function within traditions:

There is $[\ldots]$ considerable internal diversity within religions in terms of beliefs and practices, but there is also a certain ideological inelasticity which 
is brought about by a commitment to the earliest forms of a religion as the normative criterion (Turner 1976, 19).

A discourse of origins within a religious tradition, suggests Turner, points to a deep continuity between the past and the present. It reflects the 'inelasticity' and conservative side of a tradition. Turner was concerned, like many other scholars at the time, with the distinctiveness and uniqueness of religious traditions (Ortner 2002). While change and transformation within traditions could not be ignored, some theory or mechanism had to account for their continuity. Rituals, myths and discourses directed to origins were mechanisms of conservation.

Weber and Turner point us to one function of a turn to the origins, setting up a dialectic between change and continuity in that tradition. In Turner's analysis, however, the turn to the origins is wrested out of the larger discourse of which it is an essential part. In this study, I argue that there is more to be gained by turning to a deeper appreciation of the discourse of renewal within a religious tradition, in the terms used by that tradition. My example of revival proposes to show the significance of the discourse in a familiar theme or pattern generated by the discourse. I would like to show how the turn to origins was articulated in a hadith discourse of revival, and explore some of the promises and dilemmas offered by it for Muslim societies. I want to argue that neither a mythical return to origins nor a conservative ethic of routinization exhausts the significance of revival. When examined from the etic terms within the tradition, revival points rather to crisis, resolution and repeated crisis. This discursive pattern sheds further light on the turn to origins in the history and sociology of Islam.

\section{Revival in the Study of Islam}

The term revival occurs in a popular hadith cited by Sunni movements, which appears in the Sunan Abi Dawud, a book of hadìth compiled by Abū Dāwūd Sulaymān ibn al-Ash`ath al-Azdi as-Sijistānī (d. 275H/889 CE). Narrated by Abu Hurayrah, the Prophet is reported to have said:

God will raise for this community at the end of every hundred years one who will renovate (yujaddid) its religion for it (Book 37, Number 4278).

The word tajdid is a verbal noun, and refers to that which the mujaddid does. This hadith collection is considered one of the six authentic sources in Sunni 
thought. The hadith itself is regarded as authentic by Sunni Muslim scholars. It promises a mujaddid (a renewer) for Muslims at the turn of every century.

Students of Islam have debated the significance of tajdid, the subject of this hadith and its commentary. There are in fact at least three different positions identifiable in modern scholarly analysis of revival. The first position emphasizes the inherent traditionalism of Islam, the second attempts a contextual understanding of the hadith, while the third takes a constructivist approach. The first may be seen as a Weberian approach that confirms the limit of change that Turner alluded to in his paper. The other two traditions echo a more dynamic approach to renewal and revival; they are examples of how the turn to origins points to dynamic and sometimes unexpected processes at work in the history of Islam.

In an entry in the Encyclopedia of Islam, Jansen defined tajdid as a cyclical pattern of revival in the history of Islam, whereby High literate Islam 'attempt(s) to impose itself on the whole of society'. In contemporary contexts, Jansen identifies tajdìd as a rejection of foreign ideas and influences. Muslim society, he says, 'find (s) self-renewal in its own perfectly genuine and real Higher Culture which had been recognised, though not implemented, as a valid norm by the rest of Muslim society' (Jansen 2000). Jansen represented a generation of Islamicists such as Hamilton Gibb, Bernard Lewis, Gustave von Grunebaum, Ernest Gellner, van Nieuwenhuize, and to some extent Francis Robinson, who argued that there was a deep and essential continuity between Islam in the past and Islam in modern times. There are no doubt differences among these scholars, but they agree that Muslims turning to the origins of Islam produced greater Islamization and re-Islamization. This is a perspective on tajdid that sees revival as a return to the past. It was also a perspective that saw revival as resistance to change, in a way suggested by Bryan Turner.

Ella Landau-Tasseron brings a different perspective to the mujaddid hadith. Following a classic Shachtian approach to the history of hadith, she argues that the mujaddid hadith was probably put into circulation by some of the students of the jurist al-Shafi'i (d. $820 \mathrm{CE}$ ), and was used to legitimize his status and authority among other Muslim scholars. When it was first proposed, the hadith validated al-Shafi'i's legal methodology against the dominant juristic schools of the time. In a later development of this term, the mujaddid (renewer) was identified as one who fought heresy, in contrast to an earlier understanding where the mujaddid was engaged in legal reform. Landau-Tasseron's interpretation points to the employment of the concept in different contexts: to the production of a legal discourse, and its changed focus in later usage. But she also hesitates to draw any further conclusions 
from the usage, arguing that it was a not a term developed extensively by Muslim scholars in the past (Landau-Tasseron 1989).

In a co-authored article, Ebrahim Moosa and Sherali Tareen take this contextual and functionalist approach further. They argue that the employment of religious concepts always produces new developments in societies. What appeared as a return to the past in Muslim discourse was often a re-formation and re-construction. Revival might look like an imitation of the past, but it was a creative imitation. According to Moosa and Tareen, tajdìd offers a key to understanding this creative imitation in the history in Islam. They call tajdìd a 'political theology' by which Muslims returned to the past with new questions. Each time, the mere positing of new questions produced new paths of salvation. Moosa and Tareen count al-Shafi'i and al-Shātibì as reformers (mujaddidinn) who posed such questions and created new Sharia epistemologies and methodologies. They also see the emergence of a religious class in Islam as a product of tajdìd. In the modern period, they continue, tajdì has been directed at socio-political projects and rationalization. For Moosa and Tareen, tajdìd is a dynamic element in Muslim discourse, which provides the language and justification for new projects and trends. (Moosa \& Tareen 2012.)

The turn to origins, as proposed by Jansen, sets a limit to change, and confirms Turner's thesis on continuity within religious traditions. LandauTasseron and Moosa/Tareen implement a constructive approach to the employment of tajdid as offering a platform for interesting and sometimes insidious innovations not apparent on the first reading. Their critical analysis points to the 'other things' found in a tradition, as suggested by Foucault. Moosa and Tareen do not focus on the historicity of the hadith, but their essays points to the fecundity of meanings generated in the gaze to the origins. I want to deepen this critical reading of tajdìd by paying careful attention to the discourse of revival in the hadith collections and commentary. This intra- and inter-textual reading tells us the mujaddid and tajdì have characteristically been employed in a period of perceived crisis, from which a new vision had to be created. However, the seeds of crisis are always carried over to a new vision or project.

\section{The Mujaddid in the Hadith}

The collections of hadith and commentary provide a basis for deeper reflection on the hadith discourse of revival. I focus on the collection of Sunan $A b \bar{\imath} D \bar{a} w \bar{u} d$, and the commentary of a nineteenth and twentieth scholar in 
India, Muḥammad Shams al-Ḥaqq 'Aẓ̄ìmābādī (d. 1911) ('Aẓ̄imābādī \& Ibn Qayyim al-Jawziyyah 1979). I begin with the intra-textuality of the mujaddid hadith in the collection, and closely examine its place in relation to other narrations, which reveals some interesting nuances that are not apparent in the hadith as a singular citation. I then turn to the widely read commentary

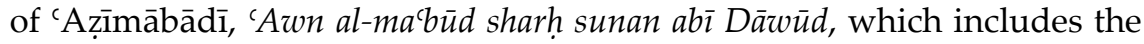
commentary of Ibn al-Qayyim al-Jawziyyah (1292-1350 CE), a prominent medieval scholar, and some unique comments by the author.

The mujaddid hadìth in question appears in Chapter 37 of Abū Dāwūd's Collection of 41 chapters ('Aẓīmābādī and Ibn Qayyim al-Jawziyyah 1979, 11:386). This chapter is entitled 'the Chapter of Wars' (Kitāb al-malāhim), and its subject matter is closely related to Chapter 35, 'Dissension and Wars' (alfitan wa 'l-malāhim), and Chapter 36, 'the First Chapter of the Guided One' (Awwal Kitāb 'l-Mahdī). The three chapters present various scenarios of what will happen to Muslims after the death of the Prophet. Chapter 35 begins with the Prophet Muhammad's detailed knowledge of those who will come after him, stressing the inevitability of dissension (fitnah) among Muslims (Hadith nos. 4221-4234; 11:303-328). Some narrations predict that a civil war among Muslims will last for 35, 36 or 37 years, after which din (religion or authority) will be established for 70 years (Hadith no. 4234; 11:327). There is a prayer from Muhammad that Muslims would not be dominated by others unless they raise their swords against each other. Other hadith advise Muslims to stay away from inevitable civil conflict, to break their swords, and to fear the eschatological consequences of killing other Muslims (Hadith, no. 4236; 11:333).

The next chapter, on the Guided Leader (al-Mahdi), includes predictions that the Prophet will be followed by 12 successors (khalifah), all from the Quraysh, who will bring justice on earth. There are also predictions of individuals who will support the family of the Prophet (Hadith nos. 4259, 4262; 11:411:361, 370). 'The Chapter of Wars' opens with the mujaddid hadith, predicting the appointment of one every century. This is followed by hadith that predict wars with the Byzantines, the fall of Constantinople, wars with Turks and Ethiopians (Hadith nos. 4271-4287; vol. 11:397-423). Again, some hadith warn of the dire consequences of civil war among Muslims. Others mention the signs of the final end of the earth, including one in which a man meets Dajjal (the one-eyed evil one) during the time of the Prophet (Hadith no. 4303; 11:469-70).

The mujaddid hadith placed in the contexts of other narrations offer interesting clues for reflection. The emergence of a mujaddid is closely associated 
with crisis (fitnah) and leadership, in the absence of the Prophet's leadership after his death; one hadith even suggests that the crisis was already looming at the end of his life: Dajjāl is already said to have appeared in Muhammad's lifetime.

Reading inter-textually, it is also clear that the mujaddidin were not the only ones promised to come after the Prophet. The cluster of hadith promises that Muslims may be saved by a number of other possible leaders: the guided one (al-Mahdi), by members of the family of the Prophet, or by the twelve Quraysh caliphs. The hadith predict that most Muslims will turn away from these leaders. Ignoring both divine decree and blood relation to the Prophet, however, the hadith tell us, many Muslims would oppose and reject the various individuals sent to lead the community. The hadith that advise Muslims to turn away from intra-Islamic conflict, by breaking their swords, and also apparently imply a potential refusal to follow these leaders,.

In his study of the emergence of the Ahmediyya Muslim Community in India in the 19th century, Friedman briefly studied the mujaddid hadith and concluded that it promises revival after a perceived crisis (Friedmann 1989, 95-97). Reading intra-textually, one can say more. The crisis reflected in the hadith was precipitated by the absence of the Prophet, but not necessarily averted by the appearance of a mujaddid. In spite of the fact that the mujaddid hadith on its own promises some form of salvation, put in relation to the other hadith it offers no guarantees. The mujaddid hadith promises salvation in a period of crisis, but also promises continued crisis and chaos.

\section{The Mujaddid in the Commentary before 'Aẓ̄māāādī}

'Aẓ̂mābādī produces a line-by-line commentary to the hadìth in these chapters. He also incorporates within his text the full commentary of Ibn alQayyim al-Jawziyyah. For this article, I would like to focus on 'Azịmābādī's comments as he repeats a history of Sunni commentary, and adds to that tradition. Both the recollection and invention are important, and help us in elucidating further the hadith discourse of renewal.

'Ażīmābādī notes that Muslim scholars throughout history have identified individuals (mujaddidin) who revived the sunnah of the Prophet. Like his predecessors, he agrees that the pious Umayyad caliph Umar b. 'Abd al-'Azīz was the first mujaddid, followed by al-Shāfi'ī. He also remarks that the former enjoyed a higher rank, since he possessed the power to carry out necessary reforms ('Aẓ̄mābādī \& Ibn Qayyim al-Jawziyyah 1979, vol 11, 393). In spite of his praise for this political leader, however, the remaining 
mujaddidīn identified are scholars. 'Aẓimmābādī occasionally reports on some differences among scholars as to the particular identity of the mujaddid at any one time. He also reproduces a history of debate on the meaning of the phrase 'at the head of every century'. Muslim scholars have argued whether the mujaddid in question would be active when the new century opened or closed ('Aẓ̂̄mābādī \& Ibn Qayyim al-Jawziyyah 1979, vol 11, 389-90). But he generally produces a clear line of succession, one mujaddid followed by another. Every hundred years, they have turned Muslim societies away from innovations $\left(b i d a^{3}\right)$, and guided them back to the sunnah [the Path, or prescribed devout way of life] of the Prophet.

This historical retrieval by 'Aẓimbābādī provides insight on how the $m u$ jaddid hadith has been interpreted by Sunni scholars. Islamic scholars in this tradition identify a line of scholarly successors who restored the ummah to its original purity. There is some contestation around individual mujaddidin, but they have all proclaimed a revival (yujaddidu) of the $\operatorname{din}$ [the Way]. There are no real alternatives included in the line of succession. 'Azịmbābādī specifically rejects the idea of Mu'tazilite or Shi'ite names offered for this office ('Azịimābādī \& Ibn Qayyim al-Jawziyyah 1979, vol. 11, 392). All the mujaddidin were successful in turning Muslims' gaze back to the past, to the pure original community, and restoring their purity and salvation.

Comparing this commentary with the hadith, a few remarks may be ventured. 'Aẓ̌imābādī's identification of a line of successive mujaddidīn was more decisive than the cluster of hadìth collected by Abū Dāwūd. The hadith portray a much more challenging task of finding a successor to the Prophet. While the hadith narratives are marked by plurality of perspective, and even express some measure of despondency, the commentary asserts that the crisis has been overcome. There was also a clear identification of the crisis, a decisive renaming. A mujaddid appeared when the sunnah was forgotten. In keeping with classical Sunni argument, the person of the Muhammad is substituted with the sunnah [the Path]. All crises in Muslim societies are marked and identified as the absence of the sunnah - and it is therefore the community of scholars who collected the sunnah who are best placed to restore the community to the straight path. The commentary erases conflict and crisis by naming the crisis and by pointing to individuals who guaranteed salvation.

The commentary confirms what both Landau-Tasseron, and Moosa and Tareen have suggested about tajdid. The mujaddid hadith is a justification for a particular scholarly tradition, as Landau-Tasseron suggests, or an important element in the production of a Sunni scholarly class more generally, as 
Moosa and Tareen argue. But we can venture to say more. Renewal (tajdìd) is a religious construct or invention that promises deliverance from crisis. Those who take up this task claim the privilege of naming the crisis. Sunni Religious scholars in particular declare that all crises in Muslim societies are characterized by the absence of the sunnah. Their redefinition conceals, however, the historically conflicted crisis evident in the cluster of hadith in the collection of Abū Dāwūd. They also conceal competing interpretations of the crises that have faced the community, competing classifications that challenge the Sunni naming.

'Aẓīmābādī's unique remarks in the commentary are worth a closer look, for understanding revival in the encounter with modernization. On some important points, 'Aẓ̂mābādī departs from his predecessors. 'Aẓimmābādī is not concerned with the particular death-date of the mujaddid and its relation to the turn of the century in the Islamic calendar. The mujaddid could appear at any time as long as he was able and willing to revive the sunnah ('Azīmābādī \& Ibn Qayyim al-Jawziyyah 1979, 11:390). Following the lead of a medieval scholar, he does not think that one should look for one reformer sent by God at the head of a century ('Aẓimāāādī \& Ibn Qayyim al-Jawziyyah 1979, 11:392-3); he suggests at least three such mujaddidin within his own time (end of the 19th century) ('Azīmābādī \& Ibn Qayyim al-Jawziyyah 1979, 11: 395-6). Azịmābādī also addresses the quality of the mujaddidīn (mujaddadiyya). They are, he says, those sent by God to take 'the place ('iwad) of the salaf, one or many' ('Aẓīmābādī \& Ibn Qayyim al-Jawziyyah 1979, 11:391). The salaf refer in a general way to the earliest exemplary Muslims. They are generally considered beacons of purity and righteousness among Sunnis in general, and Sunni scholars in particular. 'Azịmābādī says that the mujaddidin are the salaf of every epoch. Through them, one or more guides are produced for Muslims whenever the need arises ('Aẓ̂mābādī \& Ibn Qayyim al-Jawziyyah 1979, 11: 391). The mujaddid is providentially called upon by the particular condition in which Muslims find themselves.

'Ażīmābādī's new insights offer some interesting suggestions for thinking about renewal in modern times. He replaces the question of 'Who is a mujaddid?' by 'What is a tajdìd?', shifting the discussion from the identification of the person to a discussion of the nature of revival. His scholarly predecessors had determined that the absence of the sunnah was the key problem facing the Muslims, and 'Aẓ̂̄mābādī's Deobandi background predisposed him to a similar analysis. But his commentary inadvertently re-opens the question about the true nature of revival (tajdid) in Muslim societies. Since then, as I suggested in the introduction to this essay, that 
question has been answered in a variety of ways. Secondly, with his remark on the multiplicity of mujaddidin, he recalls the intra-textual meaning of the mujaddid hadìth in the collection of Abū Dāwūd. In that cluster of hadīth, more than one person was promised to save Muslims when the Prophet Muhammad was no longer present. Most of the classical commentaries had attempted to identify one mujaddid, and certainly all had ignored the plurality of claimants in the hadìth collection. 'Azịmābādī's comments were prescient in a third way. His reference to a community of reformers suggests that renewal is no longer the responsibility and prestige of one individual every one hundred years: renewal is owned by communities, groups and movements. As a social group, they are in a position to identify the immediate crisis and promise its resolution. These unique features, the reference to the quality of the mujaddidin and their plurality, open the door to renewed claims on the meaning of revival as it appears in the hadìth collection. These features in 'Azị̄mābādī's commentary allow the crisis, apparently successfully averted in the earlier history of commentary, to be re-opened.

\section{Discussion and Conclusions}

The hadith discourse on renewal adds interesting insights on the familiar trope of turning to the origins. I first presented an intra-textual analysis of the mujaddid hadith, and showed how it is closely connected with the absence of the Prophet. This absence is marked by a sense of perceived crisis. One may venture to suggest that this was an originary moment in the meaning of revival in Islam. The absence of the Prophet raised insoluble questions about his succession, which are vividly captured in the hadith narrations. Turning to the origins in the hadith collection did not produce harmony, however, as it was always marked by a pluralism which exacerbated and aggravated crisis. Crisis was thus built into the 'turn to origins' discourse. The commentary as transmitted by 'Aẓimābādī shows how the conflict was addressed and averted. Scholarship produces harmony by focusing only on one of the hadìth from Abū Dāwūd's collections, and ignoring the others. Conflict is also written out of this interpretation by naming the crisis: the absence of the sunnah. The absence of the Prophet in the hadith literature is replaced in the commentary by the absence of the sunnah. A close reading of 'Azịmābādī's commentary points to early signs of new ways of thinking about the mujaddid in modern times. The identification of the mujaddid was now replaced by a discussion of the nature of tajdìd, and the recognition 
of multiple mujaddidin. This small change opens the door to competing meanings of renewal that had been erased in the scholarly traditions. The commentary of 'Aẓ̇imābādī, particularly his creative reading, opens the door, or suggests that a crisis was again re-opening.

The hadith discourse of the mujaddid/tajdid, I will argue, is not merely a contextual and creative approach to the past. It addresses an element of recovering a critical absence in Muslim religious discourse. The first absence was the death of the Prophet; the recovery of that absence produced creativity, but the recovery was always fragile, if we remember the inter-textuality of the mujaddid hadìth in Abū Dāwūd. And of course, the theology of the finality of the Prophet ensures that the Prophet cannot be replaced in person or as a Prophet. This has not prevented reformers from promising a return to the past, however; they achieve this by re-identifying the crucial absence, and promising its restoration. Leaders and movements of renewal in the past and present may thus be said to continually re-identify and re-name the crisis, and point to its resolution. Both the naming and crisis, however, were not as obvious as they are made out to be - and both are condemned to repeat the original crisis.

In the study of religions, Mircea Eliade's approach to origins reflects very closely what the earlier Sunni scholarly tradition offered to Muslims. Their scholarly commentary was a self-validating tradition, which promised Muslims that the mujaddidin, first individually and now collectively, would lead Muslims back to the Prophet. The scholars did what Eliade identified. Their myths and rituals transported participants to an original pure moment, beyond history and beyond chaos. A closer look at the hadith discourse reveals a more fractured and composite picture. Firstly, there is a discourse of revival that calls for closer scrutiny as it was employed over time and place. In this article, I have placed the turn to origins within this discursive tradition of Muslim scholars, and find that the origins promised through tajdid are in fact not primordial and pointing to a point beyond chaos, but produced in crisis. The mujaddid did not emerge with the Prophet, but after him in his absence. The tajdìd discourse reveals a deep crisis in the foundation of revival in Islam, and Muslim renewal movements and discourses have grappled with this crisis through a process of (re-)naming, recalling and invention, in which the crisis was now solved or hidden, now revealed and ruptured. 
Bibliography

Ahmad, Aziz

1967 Islamic Modernism in India and Pakistan, 1857-1964. London [etc.]: Oxford University Press.

Asad, Talal

1986 The Idea of an Anthropology of Islam. Washington, D.C.: Center for Contemporary Arab Studies, Georgetown University.

'Aẓ̄imābādī, Muhạammad Shams al-Ḥaqq (d.1911) \& Abū Abdullah Muhammad b Abi Bakr al-Zar'i al-Dimishqi Ibn Qayyim al-Jawziyyah (d. 1350)

1979 'Awn al-ma'būd sharh sunan ab̄̄ Dāwūd. Beirut: Dār al-Fikr.

Dallal, Ahmad

1993 The Origins and Objectives of Islamic Revivalist Thought, 1750-1850 - Journal of American Oriental Society 133 (iii), 341-59.

Eliade, Mircea

1959 Cosmos and History: The Myth of the Eternal Return. New York, NY: Harper \& Brothers.

1964 The Quest for the 'Origins' of Religion - History of Religions 4 (1), 154-69.

Foucault, Michel

1977 Nietzche, Genealogy, History. - D. F. Bouchard (ed.), Language, Counter-memory, Practice: Selected Essays and Interviews, 139-164. Ithaca, NY: Cornell University Press.

\section{Friedmann, Yohanan}

1989 Prophecy Continuous: Aspects of Ahmadi Religious Thought and Its Medieval background. Berkeley, CA: University of California Press.

\section{Gellner, Ernest}

1981 Muslim Society. Cambridge: Cambridge University Press.

Gerth, H. H. \& C. Wright Mills (eds)

1970 From Max Weber: Essays in Sociology. London: Routledge and Kegan Paul Ltd.

\section{Gilsenan, Michael}

1990 Recognizing Islam: Religion and Society in the Modern Middle East. New York, London: I. B. Taurus.

\section{Humphreys, R. Stephen}

1982 The Contemporary Resurgence in the Context of Modern Islam. - Ali E. Hillal Dessouki (ed.), Islamic Resurgence in the Arab World, 67-83. New York, NY: Praeger 
Jansen, J. J. G.

2000 Tadjdīd. - P. Bearman et al. (eds), Encyclopedia of Islam, Second Edition, 61-2. Leiden: Brill.

\section{Landau-Tasseron, Ella}

1989 The 'Cyclical Reform': A Study of the Mujaddid Tradition. - Studia Islamica 7079-117.

Martin, B. G.

1976 Muslim Brotherhoods in Nineteenth-century Africa. Cambridge: Cambridge University Press.

\section{Masuzawa, Tomoko}

1989 Original Lost: An Image of Myth and Ritual in the Age of Mechanical Reproduction. -The Journal of Religion 69 (3), 307-25.

2000 Origin. - Willi Braun \& Russel T. McCutcheon (eds), Guide to the Study of Religion, 209-24. London: Cassell.

\section{Meijer, Roel}

2009 Introduction. - Roel Meijer (ed.), Global Salafism: Islam's New Religious Movement, 1-32. London: Hurst \& Company.

\section{Metcalf, Barbara D.}

2002 Traditionalist Islamic Activism: Deoband, Tablighis, and Talibs. Leiden: ISIM.

\section{Moosa, Ebrahim \& Sherali Tareen}

2012 Revival and Reform. - Gerhard Bowering (ed.), The Princeton Encyclopedia of Islamic Political Thought, 100-110. Princeton, NJ: Princeton University Press.

\section{Ortner, Sherry}

2002 On Key Symbols. - Michael Lambek (ed.), A Reader in the Anthropology of Religion, 158-67. Malden, MA, \& Oxford: Blackwell Publishing.

\section{Roff, William R.}

1987 Islamic Movements: One or Many? - William R. Roff (ed.), Islam and the political economy of meaning, 31-52. London: Croom Helm.

\section{Turner, Bryan S.}

1976 Origins and Traditions in Islam and Christianity - Religion 6 (1), 13-30. 
